\title{
The Influence of Macro Factors on the Exit of Venture Capital-Take the Chinese Market as an Example
}

\author{
Xiaolin Yang \\ Business School, Beijing Normal University, Beijing, China \\ Email: xiaolinyang2017@163.com
}

How to cite this paper: Yang, X.L. (2018) The Influence of Macro Factors on the Exit of Venture Capital-Take the Chinese Market as an Example. Modern Economy, 9, 1301-1312.

https://doi.org/10.4236/me.2018.97084

Received: July 3, 2018

Accepted: July 23, 2018

Published: July 26, 2018

Copyright $\odot 2018$ by author and Scientific Research Publishing Inc. This work is licensed under the Creative Commons Attribution International License (CC BY 4.0).

http://creativecommons.org/licenses/by/4.0/

\section{cc) (i) Open Access}

\begin{abstract}
We control the investor and investment-specific factors to test how macro factors affect the exit of venture capital. After using a sample of $28668 \mathrm{VC}$ investments in China, we discover that macro factors such as legal rights and GDP growth have a positive impact on successful exit, which means that macro factors can increase the likelihood of successful exit. Surprisingly, market liquidity which is one kind of macro factors can significantly reduce the likelihood of trade sale, which is different from our predictions. In addition, we find that the VC-backed firms with more amount investment and bigger syndicate size will have more opportunities to IPO, but the VC investors with more experience will decrease the likelihood of trade sale and liquidation.
\end{abstract}

\section{Keywords}

Venture Capital, IPO, Trade Sale, Liquidation, Macro Factors

\section{Introduction}

Venture capital is an important part of the financial market and was first formed in developed countries. After long-term development, the important role of venture capital in the development of the innovative economy and regional economic growth has been widely recognized. At present, venture capital is developing rapidly on a global scale. With the exception of the United States and Western Europe, venture capital has spread to many countries including China.

Relative to the venture capital market in developed countries, Chinese venture capital investment started relatively late. In 1985, China established the first venture capital institution, China New Technology Venture Capital, which is still in the initial stage of venture capital development. At the same time, venture 
capital institutions with foreign background continued to enter the Chinese market, which promoted the development of Chinese venture capital market.

The current literature shows that macro factors have an important impact on the exit of venture capital [1]-[7], and we find in some markets that the higher the market liquidity, the better the legal rights and the better the economic environment, the higher the probability of successful exit of venture capital. So our article focuses on whether these effects of macro factors continue to exist in emerging markets. This is an important role for both cross-border investors and local investors when investing, and also plays an important guiding role for national economic managers in promoting economic development.

We use a sample of 28,668 VC investment events in China to verify these hypotheses. After controlling for investor and investment-specific characteristics, we use different methods and reveal several important results.

First, we find that market liquidity has a positive impact on IPO exit, but it is not statistically significant. What's more, the increase in market liquidity will significantly reduce the probability of trade sale. In addition, market liquidity cannot make the non-performing investments write off quicker.

Second, we found that legal rights can increase the likelihood of IPO and trade sale. For liquidation, the result is not significant.

Third, we find that GDP growth can increase the likelihood of IPO and trade sale. For liquidation, the result is not significant. However, after controlling for potential endogenous biases, the positive impact of macroeconomic levels on IPO exits is not significant.

Fourth, for the control variables, we find that the increase in the size of Syndicate and the amount of equity deal can significantly increase the probability of successful IPO exit, but the increase in VC experience will significantly reduce the probability of exit by trade sales and liquidation.

In general, macro factors, such as legal rights, and GDP growth can increase the likelihood of successful exits, but market liquidity can significantly reduce the likelihood of trade sale, which is different from our predictions. Our study contributes to the literature on venture capital. Previous literature focuses more on the successful exit of venture capital such as IPO, while we focus only on IPO but also trade sale and liquidation. But in our paper, we just pay attention to one country on an emerging market, and I think it's better to use more country sample to test the hypotheses.

The structure of the article is as follows. Next, we show the literature review. Then, we introduce the data and methodology that we use. After that, we report the results according to our analysis. In the end, we make conclusions.

\section{Literature Review and Development of Hypotheses}

Venture capital is finite life and the exit is the driving force of the venture capital [8]. The exit plays a critical role in the VC firm because the successful exit can provide support for the VC firms' developing [6] [9]. There are two kinds of way 
of exit. First is successful exit including IPO (initial public offering) and trade sale (mergers and acquisitions and trade sale). Second is failure exit, such as liquidation, repurchase. In our article, we use liquidation to represent the failure exit.

\section{Which Factors Infect Exits}

According to the literature, researchers find that macro-environment and micro factors have significant influence to exit. Macro factors include market liquidity, legal rights and macroeconomic and micro factors include investee firms, VC investors, and investments characteristics.

First of all, we will discuss the influence of macro factors on exit. At the beginning, market liquidity can affect the likelihood of exit. Black and Gilson [9] show that there is some relationship between stock market and venture capital, and the active stock market will attract the VC to choose IPO to exit. Nahata et al. [2] demonstrate that stock market will affect VC performance and stock market is positively correlated with successful exits in both developed and emerging economies. Then, Bertoni and Groh [1] demonstrate that not only the local stock market but also local M \& A market is positive to the successful exit in Europe.

Next, legal rights have an influence on the exit. Cumming et al. [5] demonstrate that higher Legality index will facilitate the likelihood of IPO exit than stock market after controlling for the factors that may affect exit. And then, Nahata et al. [2] find better legal rights facilitate the likelihood of VC successful exits. What's more, Espenlaub et al. [3] discover that the better legal rights can speed up the time to IPO exit.

Then, Macroeconomic can affect the likelihood of exit. Different researchers get different results about the relationship between the macroeconomic and exit of venture capital. On the one hand, Wang and Wang [4] demonstrate that the if the GDP's performance is better, the likelihood of exit will decrease. And then, Espenlaub et al. [3] get the same results. On the other hand, other researchers find that if the economy in one country is the good performance, this will affect the stock and M \& A market, which will increase the likelihood of exit [5] [6] [7].

Second, we will discuss the influence of micro factors on exit. Investee companies, investors and investments characteristics will have an influence on exit. Bertoni and Groh [1] find that the sales growth, patent stock and total assets can affect the likelihood of exit. Total assets are positively correlated with IPO and sales growth and patent stock are negatively correlated with trade sale. Wang and Wang [4] demonstrate that the experience of the VC can enhance the likelihood of exit. And Espenlaub et al. [3] find that the experience of the VC can reduce the time of successful exit. Syndication between foreigner investors and domestic investors will exit earlier from the underperforming firms [1]. Dai et al. [10] demonstrate that syndication has a positive implication for the exit performance.

Guo et al. [11] find that the duration and size of an investment will influence 
the choice of exit. Ozmel et al. [12] [13] demonstrate that the number of financing rounds affects the choice of exit. Bacon-Gerasymenko et al. [14] show that the initial and revised VC investor's forecasts also will affect the choice of exit.

And the cross-border investments have an influence on exit. On the one hand, Bertoni and Groh [1] demonstrate that cross-border investment can bring additional chance for $\mathrm{VC}$ backed firms to exit compared to the domestic investment. On the other hand, Espenlaub et al. [3] show that the foreign investors exit faster than domestic investors.

According to the summary of literature review, we find that many papers focus on successful exits, but in our paper, we also focus on the failure exit. And there are many papers focus on how fast the venture capital will exit, while we focus on how macro factors affect the likelihood of exits. We know that from Black and Gilson [9], the stock market has a significant influence on the likelihood of exit. Then, Nahata et al. [2] and Bertoni and Groh [1] demonstrate that market liquidity can increase the likelihood of successful exits. So we wonder that if market liquidity can increase the likelihood of successful exits in China and we formulate the first hypothesis:

H1: Market liquidity can increase the likelihood of IPO and trade sale.

Next, we find that Cumming et al. [5] and Nahata et al. [2] demonstrate that legal rights can facilitate the likelihood of IPO exit, and we also think there may be the same impact on the trade sale, so we formulate the second hypothesis:

H2: Legal rights can increase the likelihood of IPO and trade sale.

Then, we find that different researchers discover different results for GDP growth. On the one hand, Wang and Wang [4] and Espenlaub et al. [3] demonstrate that GDP's performance can reduce the likelihood of exit. On the other hand, good economic performance will increase the likelihood of exit [5] [6] [7]. So we formulate the next two hypotheses:

\section{H3a: GDP growth can reduce the likelihood of IPO and trade sale.}

\section{H3b: GDP growth can increase the likelihood of IPO and trade sale.}

\section{Data and Methodology}

In this section, we will introduce the investments data and other data that we will use and we also introduce the methodology that why we use.

\subsection{Sample}

The investments data of our sample come from the Zero2IPO database, which was one professional data platform for Chinese venture capital investment. And we choose the investment period from 20070101-20161231 and select the companies' founding after 1996. What's more, the exit information of our sample ended in 2017. And we delete some data because they do not have the complete information. After that, we get a sample of 10,889 companies and 28,668 VC investment events.

Figure 1 shows the distribution of investment events from 2007 to 2016 . We find that the investment events in 2007 are the least, with only 1040, and the 


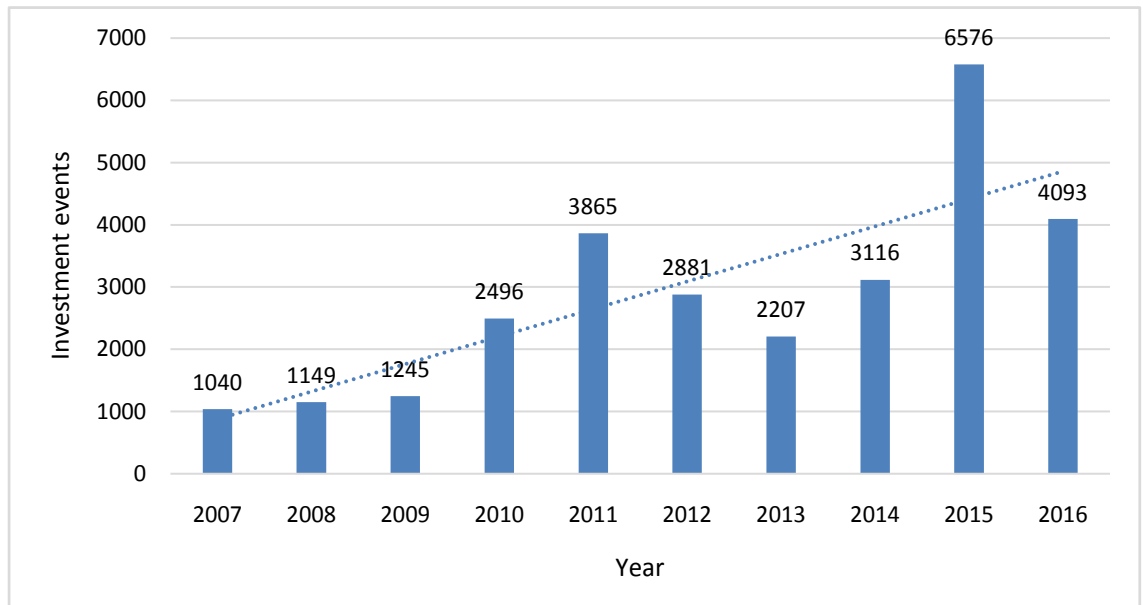

Figure 1. Distribution of investment events from 2007 to 2016.

most investment events in 2015 reached 6576, about 6.5 times than that of 2007. On the whole, we find that the trend line is tilted upwards, which means that investment events are increasing over time.

Table 1 represents the distribution of different types of exit events. We find that the ratio of cross-border investors that exited is $14.0 \%$, which is higher than the domestic investor about $8.4 \%$. This difference is mainly due to the exit of IPO. The ratio of IPO exit by cross-border investors is $10.1 \%$, while the ratio of local investors is only 5.1\%. For this result, on the one hand, cross-border investors may be more inclined to invest in companies that perform better, and on the other hand, those companies that perform better will attract more cross-border investors.

\subsection{Methodology and Variables}

The main purpose of this paper is to look at the impact of macro variables on the probability of venture capital exit. First of all, our data is right censored. At the end of 2017, there are still many investment events that have not been exited. Secondly, these three exit methods IPO, Trade sale, Liquidation cannot happen simultaneously, so we can believe that from the different channels, there is competition. So such as Bertoni and Groh [1], we use the semi-parametric competing-risks model which developed by Fine and Gray [15] to test our hypotheses.

In order to examine the impact of macro factors on the exit of venture capital, we need to control the micro factors that may affect the probability of exit, including the characteristics of investors and the characteristics of investment events. First, the characteristics of investors include whether investors are cross-border investors and VC experience. We predict that cross-border investors and VC experience will increase the likelihood of successful exit. Second, the characteristics of investment events include follow on, Syndicate size, Equity Amount deal, and we predict that follow on, Syndicate size, Equity Amount deal can increase the likelihood of successful exit. Then, on the basis of controlling 
Table 1. Distribution of investments by type of exit.

\begin{tabular}{ccccccccccc}
\hline & \multicolumn{2}{c}{ Exited } & \multicolumn{2}{c}{ IPO } & \multicolumn{2}{c}{ Trade-sale } & \multicolumn{2}{c}{ Liquidation } & \multicolumn{2}{c}{ No exit } \\
& $\mathrm{N}$ & $\%$ & $\mathrm{~N}$ & $\%$ & $\mathrm{~N}$ & $\%$ & $\mathrm{~N}$ & $\%$ & $\mathrm{~N}$ & $\%$ \\
\hline Cross-border & 338 & 14.0 & 244 & 10.1 & 78 & 3.2 & 16 & 0.7 & 2077 & 86.0 \\
Local & 2201 & 8.4 & 1328 & 5.1 & 728 & 2.8 & 145 & 0.6 & 24052 & 91.6 \\
Total & 2539 & 8.9 & 1572 & 5.5 & 806 & 2.8 & 161 & 0.6 & 26129 & 91.1 \\
\hline
\end{tabular}

the corresponding control variables, we need to add macro factors, such as market liquidity, legal rights, and GDP growth to the model. Market liquidity refers to the liquidity of domestic stocks, legal rights refer to the domestic legal environment, and GDP growth rate refers to the domestic economic environment. Table 2 provides a detailed definition and measurement of the variables.

In addition, we also use the propensity score matching method to process the data. In this step, we estimate the propensity score of VC investments to be conducted by a cross-border investor. We use a series of observable characteristics, such as companies' age, the amount deal of equity, and industry, as covariates. And we pick five nearest neighbors' local investment. After that, we obtain the corresponding matching samples, and then use the competing risks model to perform regression to eliminate the potential endogenous bias and verify the robustness of the results.

In summary, our basic regression models are:

Competing risk model:

$$
\begin{aligned}
& \text { the probability of exit(IPO, trade sale or liquidation) } \\
& =\alpha_{1} \text { control factors (investors and investments characteristics) } \\
& +\alpha_{2} \text { macro factors (market liquidity, legal rights, or GDP growth) }
\end{aligned}
$$

\subsection{Descriptive Statistics}

Table 3 is a descriptive statistical analysis of the variables. For the control variables, we find that $45.9 \%$ of the investors participated in the follow on investment, and the average number of joint investors was 2.7. In addition, for macro factors, we found that Chinese legal rights are only -0.507 , and the average GDP growth rate is $8.2 \%$.

\section{Results}

The purpose of our return is to look at the impact of macro factors on the exit of venture capital. In order to achieve our goals, we first need to control the characteristics of investors and investment events, because these factors can affect the probability of venture capital exit, including whether investors are cross-border investors, whether the investment has a subsequent round, the number of joint investment participants, the size of each round of investment, and the experience of VC. Secondly, after controlling these factors, we need to add 
Table 2. Definitions of variables.

\begin{tabular}{|c|c|}
\hline Variable & Definition of variable and unit of measurement \\
\hline Cross-border & $\begin{array}{l}\text { A dummy variable equals to one if the investment is invested } \\
\text { by cross-border investors, and zero for domestic investors. }\end{array}$ \\
\hline Follow-on & $\begin{array}{l}\text { A dummy variable equals to one if the investor entered in a follow-on } \\
\text { financing round and equal to zero for others. }\end{array}$ \\
\hline Syndicate size & Number of VC investors in parallel at time t. \\
\hline Equity amount deal & $\begin{array}{l}\text { The natural logarithm of equity amount invested by all investors in } \\
\text { the deal in USD dollars. }\end{array}$ \\
\hline VC experience & $\begin{array}{l}\text { VC experience measured as (the logarithm of) the difference } \\
\text { (in years) between the founding date and the date of investment. }\end{array}$ \\
\hline Market liquidity & $\begin{array}{l}\text { The volume of IPOs (source: Thomson One Banker) in the host } \\
\text { country divided by host country's GDP. }\end{array}$ \\
\hline Legal rights & $\begin{array}{l}\text { Such as Li and Zahra [16], we use the average of six broad dimensions } \\
\text { of governance including Voice and Accountability, Political Stability } \\
\text { and Absence of Violence/Terrorism, Government Effectiveness, } \\
\text { Regulatory Quality, Rule of Law and Control of Corruption to } \\
\text { represent the quality of legal rights in the host country } \\
\text { (source: Worldwide Governance Indictors). }\end{array}$ \\
\hline GDP growth & The growth of GDP in the host country (source: World Bank). \\
\hline
\end{tabular}

Table 3. Summary statistics.

\begin{tabular}{cccccc}
\hline Variable & Obs & Mean & Std. Dev. & Min & Max \\
\hline Cross-border & 28,668 & 0.084 & 0.278 & 0 & 1 \\
Follow-on & 28,668 & 0.459 & 0.498 & 0 & 1 \\
Syndicate size & 28,668 & 2.791 & 2.302 & 1 & 18 \\
Equity amount deal & 23,810 & 13.368 & 1.629 & 6.908 & 20.240 \\
VC experience & 28,668 & 0.712 & 0.418 & 0 & 2.318 \\
Market liquidity & 28,668 & 0.027 & 0.016 & 0.008 & 0.051 \\
Legal rights & 28,668 & -0.507 & 0.055 & -0.576 & -0.421 \\
GDP growth & 28,668 & 0.082 & 0.017 & 0.067 & 0.142 \\
\hline
\end{tabular}

macro factors, such as market liquidity, legal rights, and GDP growth, and see the impact of macro factors on the exit of venture capital, which can prove our hypotheses.

First of all, we use the competing risks model to regress the full sample, and the results are shown in Table 4. In fact, standard error is related with P-value, which can be used for significant. For the control variables, first, we find that the coefficient of cross-border investors about IPO is positive and statistically significant, which means cross-border investors can significantly increase the likelihood of IPO exit relative to domestic investors. But for the trade sale, cross-border investors can significantly decrease the likelihood of trade sale, which is different from our expectations. For liquidation, the results are not significant. Second, the coefficient of follow on about IPO is not significant, but for 
Table 4. IPO, trade sales and liquidation: competing risks models on full sample.

\begin{tabular}{|c|c|c|c|}
\hline & IPO & Trade sale & Liquidation \\
\hline \multirow[t]{2}{*}{ Cross-border } & $0.2456^{\star * *}$ & $-0.3353^{\star *}$ & 0.1280 \\
\hline & $(0.0832)$ & $(0.1575)$ & $(0.2900)$ \\
\hline \multirow[t]{2}{*}{ Follow-on } & 0.0544 & $0.1837^{\star *}$ & $0.3012^{*}$ \\
\hline & $(0.0545)$ & $(0.0807)$ & $(0.1717)$ \\
\hline \multirow[t]{2}{*}{ Syndicate size } & $0.0252^{\star *}$ & -0.0153 & -0.0091 \\
\hline & $(0.0106)$ & $(0.0206)$ & $(0.0454)$ \\
\hline \multirow[t]{2}{*}{ Equity amount deal } & $0.2324^{\star * *}$ & -0.0111 & -0.0819 \\
\hline & $(0.0191)$ & $(0.0284)$ & $(0.0574)$ \\
\hline \multirow[t]{2}{*}{ VC experience } & $-0.2644^{* * *}$ & $-0.2354^{\star *}$ & $-0.5223^{\star * *}$ \\
\hline & $(0.0628)$ & $(0.0934)$ & $(0.1834)$ \\
\hline \multirow[t]{2}{*}{ Market liquidity } & 5.2169 & $-20.6723^{\star * \star}$ & -3.4645 \\
\hline & $(3.8200)$ & $(5.7019)$ & $(14.0005)$ \\
\hline \multirow[t]{2}{*}{ Legal rights } & $6.8356^{* * *}$ & $7.6990^{* * *}$ & -3.0169 \\
\hline & $(1.1152)$ & $(1.7036)$ & $(4.2056)$ \\
\hline \multirow[t]{2}{*}{ GDP growth } & $9.9921^{\star * *}$ & $18.9938^{* * *}$ & 7.2039 \\
\hline & $(2.5390)$ & $(3.6812)$ & $(8.3839)$ \\
\hline$N$ & 23810 & 23810 & 23810 \\
\hline
\end{tabular}

Standard errors in parentheses. ${ }^{*} p<0.1,{ }^{* *} p<0.05,{ }^{* *} p<0.01$.

the trade sale, follow on can significantly increase the likelihood of trade sale. For liquidation, we find that as investment rounds increase, follow on can make the non-performing investments write off quicker. Third, the coefficient of syndicate size is significantly positive about IPO, which means the greater the number of joint investment, the greater the probability of IPO. For trade sale and liquidation, the results are not significant. Fourth, the coefficient of Equity Amount deal is significantly positive about IPO, which means the larger the scale of each round of investment, the greater the probability of IPO, and this is consistent with our expectations. For trade sale and liquidation, the results are not significant. Fifth, the coefficient of VC experience is significantly negative about IPO, which means the increase in VC experience will reduce the probability of IPO. At the same time, we also find that VC experience will reduce the likelihood of trade sale and liquidation. These results are inconsistent with our expectations. On the one hand, the reason may be that the increase in the survival time of venture capital does not mean that the experience of venture capital investors increases. On the other hand, it may be the complexity of emerging markets. The accumulated experience for venture capital is not universal.

For the macro factors, we find that market liquidity can significantly reduce the probability of trade sale, while for IPO and liquidation, the results are not significant. So hypothesis 1 has not been verified. Second, the higher the legal 
rights, the greater the possibility of IPO and trade sale. For liquidation, the results are not significant. So hypothesis 2 is verified. Third, the higher the economic growth rate will significantly increase the probability of IPO and trade sale. For liquidation, the results are not significant. So hypothesis $3 \mathrm{~b}$ is verified.

Next, we use the matched sample to regress, and the results are shown in $\mathrm{Ta}$ ble 5. We found that follow on, Syndicate size, and Equity Amount deal may be related to factors we have not found that affect the quality of the company, and we should control these factors. So we use the propensity score matching method to obtain the matching sample to eliminate potential endogenous biases.

After regression, we found that for control variables, Cross border's previous significant positive impact on IPO and trade sale no longer exists. Next, follow on can significantly increase the likelihood of IPO, but the significant impact on trade sale and liquidation no longer exists. Then, Syndicate size and Equity Amount deal can still significantly increase the probability of IPO, and we find that the increase in the size of Syndicate will significantly reduce the possibility of the trade sale. In the end, the impact of VC experience on IPO has disappeared, but the significant negative impact on trade sale and liquidation still exists.

For the macro factors, we find that market liquidity will significantly reduce the probability of trade sale, while for IPO and liquidation, the results are not

Table 5. IPO, trade sales and liquidation: competing risks models on matched sample.

\begin{tabular}{|c|c|c|c|}
\hline & IPO & Trade sale & Liquidation \\
\hline \multirow[t]{2}{*}{ Cross-border } & 0.1623 & -0.2711 & 0.1638 \\
\hline & $(0.1032)$ & $(0.1822)$ & $(0.3219)$ \\
\hline \multirow[t]{2}{*}{ Follow-on } & $0.1860^{* *}$ & 0.0641 & 0.2693 \\
\hline & $(0.0900)$ & $(0.1554)$ & $(0.3391)$ \\
\hline \multirow[t]{2}{*}{ Syndicate size } & $0.0341^{\star *}$ & $-0.0994^{\star *}$ & 0.0279 \\
\hline & $(0.0160)$ & $(0.0439)$ & $(0.0598)$ \\
\hline \multirow[t]{2}{*}{ Equity amount deal } & $0.2568^{* * *}$ & 0.0648 & 0.0402 \\
\hline & $(0.0299)$ & $(0.0469)$ & $(0.1038)$ \\
\hline \multirow[t]{2}{*}{ VC experience } & 0.0986 & $-0.3555^{\star *}$ & $-0.5927^{\star}$ \\
\hline & $(0.1091)$ & $(0.1694)$ & $(0.3305)$ \\
\hline \multirow[t]{2}{*}{ Market liquidity } & 2.2365 & $-46.8143^{* * *}$ & 26.7680 \\
\hline & $(5.5546)$ & $(14.1710)$ & $(22.4216)$ \\
\hline \multirow[t]{2}{*}{ Legal rights } & $5.8391^{\star * *}$ & $11.8239^{* * *}$ & -10.6704 \\
\hline & $(1.7399)$ & $(3.3459)$ & $(7.0285)$ \\
\hline \multirow[t]{2}{*}{ GDP growth } & 3.4346 & $34.2945^{\star * *}$ & -5.6190 \\
\hline & $(3.7400)$ & $(8.0970)$ & $(12.2196)$ \\
\hline$N$ & 6611 & 6611 & 6611 \\
\hline
\end{tabular}

Standard errors in parentheses. ${ }^{*} \mathrm{p}<0.1,{ }^{* *} \mathrm{p}<0.05,{ }^{* * *} \mathrm{p}<0.01$. 
significant. Second, legal rights can increase the likelihood of IPO and trade sale. But for liquidation, the result is not significant. Third, GDP growth can increase the likelihood of trade sale. But for IPO and bankruptcy liquidation, the results are not significant.

After using the full sample and the matching sample, we obtain the following robust conclusions. First of all, for the control variables, we find that syndicate size and equity Amount deal can significantly increase the probability of IPO, but VC experience will significantly reduce the probability of trade sale and liquidation. Next, for the macro factors, we find that the increase of market liquidity will not lead to an increase in the probability of IPO. On the contrary, it will lead to a decrease in the probability of trade sale. Second, we find that legal rights can increase the likelihood of IPO and trade sale. Third, we find GDP growth can increase the likelihood of trade sale.

\section{Conclusions}

Our study wants to discuss how macro factors affect the probability of the venture capital by different types of exits. We use a sample of 28,668 VC investments in China between 2007 and 2016. After controlling for the investor, investment factors and using different methods, we get the robust results.

First, we find that market liquidity has a positive impact on IPO, but it is not statistically significant. What's more, the increase in market liquidity will significantly reduce the probability of trade sale. The possible reason is that as the liquidity of the market liquidity increases, investors prefer most successful exit that is IPO.

Second, we find that the better the legal rights, the greater the probability of IPO and trade sale. For liquidation, the results are not significant. Therefore, as a national manager, in order to promote the development of the economy, we can strengthen the construction of legal rights.

Third, we find that the better the macroeconomic level, the greater the probability of IPO and trade sale. For liquidation, the results are not significant. However, after controlling for potential endogenous biases, the positive impact of macroeconomic levels on IPO is not significant.

Fourth, for the control variables, we find that the increase in the size of Syndicate and the amount of equity deal can significantly increase the probability of IPO, but the increase in VC experience will significantly reduce the probability of exit by trade sale and liquidation. This result is inconsistent with our expectations. On the one hand, the reason may be that the increase in the survival time of venture capital does not mean that the experience of venture capital investors increases. On the other hand, it may be the complexity of emerging markets. The accumulated experience for venture capital is not universal.

In general, macro factors such as legal rights, and GDP growth will increase the likelihood of a successful exit. Therefore, for venture capital investors, macro factors are important factors affecting the exit of venture capital. In the process 
of investment, it is necessary to invest more capital in countries with high good legal rights, and high GDP growth. For regulators or national managers, it is necessary to focus on improving the macro environment of the country to attract more venture capital to invest in the domestic market which can promote the development of the economy.

\section{Conflicts of Interest}

The authors declare no conflicts of interest regarding the publication of this paper.

\section{References}

[1] Bertoni, F. and Groh, A.P. (2014) Cross-Border Investments and Venture Capital Exits in Europe. Corporate Governance: An International Review, 22, 84-99. https://doi.org/10.1111/corg.12056

[2] Nahata, R., Hazarika, S. and Tandon, K. (2014) Success in Global Venture Capital Investing: Do Institutional and Cultural Differences Matter? Journal of Financial \& Quantitative Analysis, 49, 1039-1070. https://doi.org/10.1017/S0022109014000568

[3] Espenlaub, S., Khurshed, A. and Mohamed, A. (2015) Venture Capital Exits in Domestic and Cross-Border Investments. Journal of Banking \& Finance, 53, 215-232. https://doi.org/10.1016/j.jbankfin.2014.11.014

[4] Wang, L. and Wang, S. (2012) Economic Freedom and Cross-Border Venture Capital Performance. Journal of Empirical Finance, 19, 26-50.

https://doi.org/10.1016/j.jempfin.2011.10.002

[5] Cumming, D., Fleming, G. and Schwienbacher, A. (2006) Legality and Venture Capital Exits. Journal of Corporate Finance, 12, 214-245.

https://doi.org/10.1016/j.jcorpfin.2004.12.004

[6] Cumming, D. and Johan, S.A.B. (2008) Preplanned Exit Strategies in Venture Capital. European Economic Review, 52, 1209-1241. https://doi.org/10.1016/j.euroecorev.2008.01.001

[7] Cumming, D., Schmidt, D. and Walz, U. (2010) Legality and Venture Capital Governance around the World. Journal of Business Venturing, 25, 54-72. https://doi.org/10.1016/j.jbusvent.2008.07.001

[8] Gompers, P. and Lerner, J. (2001) The Venture Capital Revolution. Journal of Economic Perspectives, 15, 145-168. https://doi.org/10.1257/jep.15.2.145

[9] Black, B.S. and Gilson, R.J. (1998) Venture Capital and the Structure of Capital Markets: Banks versus Stock Markets 1. Journal of Financial Economics, 47, 243-277. https://doi.org/10.1016/S0304-405X(97)00045-7

[10] Dai, N., Jo, H. and Kassicieh, S. (2012) Cross-Border Venture Capital Investments in Asia: Selection and Exit Performance. Journal of Business Venturing, 27, 666-684. https://doi.org/10.1016/j.jbusvent.2011.04.004

[11] Guo, B., Lou, Y. and Pérez-Castrillo, D. (2015) Investment, Duration, and Exit Strategies for Corporate and Independent Venture Capital-Backed Start-Ups. Journal of Economics \& Management Strategy, 24, 415-455. https://doi.org/10.1111/jems.12097

[12] Ozmel, U., Reuer, J.J. and Gulati, R. (2013) Signals across Multiple Networks: How venture Capital and Alliance Networks Affect Interorganizational Collaboration. Academy of Management Journal, 56, 852-866. 
https://doi.org/10.5465/amj.2009.0549

[13] Ozmel, U., Robinson, D.T. and Stuart, T.E. (2013) Strategic Alliances, Venture Capital, and Exit Decisions in Early Stage High-Tech Firms. Journal of Financial Economics, 107, 655-670. https://doi.org/10.1016/j.jfineco.2012.09.009

[14] Bacon-Gerasymenko, V., Coff, R. and Durand, R. (2016) Taking a Second Look in a Warped Crystal Ball: Explaining the Accuracy of Revised Forecasts. Journal of Management Studies, 53, 1292-1319. https://doi.org/10.1111/joms.12207

[15] Fine, J.P. and Gray, R.J. (1999) A Proportional Hazards Model for the Subdistribution of a Competing Risk. Publications of the American Statistical Association, 94, 496-509. https://doi.org/10.1080/01621459.1999.10474144

[16] Li, Y. and Zahra, S.A. (2012) Formal Institutions, Culture, and Venture Capital Activity: A Cross-Country Analysis. Journal of Business Venturing, 27, 95-111. https://doi.org/10.1016/j.jbusvent.2010.06.003 